\title{
The Present Status of the Development of Mineral Resources in Sri Lanka
}

\author{
D. JAYAWARDENA \\ Geological Survey Department, Colombo 2.
}

(Date of receipt: 23 January 1984)

(Date of acceptance: 9 May 1984)

\begin{abstract}
The development of mineral resources is a vital pre-requisite for the rapid expansion of the economy of Sri Lanka. During the past five years the mineral sector has recorded a significant growth with the expansion of the gem trade, export of petroleum products and ceramic-ware. Increased export earnings from graphite, heavy mineral sands and mica have also been noted. The rapid growth in the cement industry utilizing local mineral raw materials was helpful in meeting the demand for cement due to the unprecedented increase in construction activity. The main constraint in the rapid expansion of the mineral sector is the lack of proper assessment of the mineral resources in the Island. The Geological Survey Department has taken up the challenge of locating new mineral deposits and also to carry out development of known mineral resources with the main objectives of assessment of the quality and quantity available for exploitation. Systematic exploitation of these non-rencwable resources is a vital factor, if the local mineral-based industries are to expand to meet increased demands in the future. An attempt has been made in this paper to describe the development of the mineral resources of Sri Lanka that are presently utilized by the various industrial sectors and also exploited for export in raw form. Recent mineral discoveries such as rock phosphate, copper-magnetite ore which are of economic significance and the utilization of these minerals for estabtishment of new industries are also described. The paper also discusses target areas for future mineral exploration programmes.
\end{abstract}

\section{Introduction}

The Island of Sri Lanka is located at the southernmost tip of the Indian Subcontinent and covers a surface area of 65,610 sq. kilometers with a maximum length of $435 \mathrm{~km}$ and a maximum breadth of $225 \mathrm{~km}$. The mid year population in 1982 was 15.2 million as compared to 15 million in 1981. The Gross National Product (GNP) at current factor cost prices was provisionally estimated at Rs. 89.7 billion in 1982. The per capita GNP at current prices in 1982 has been estimated as Rs. 5,904 (US \$ 284) compared with Rs. 5,179 (US \$ 267) in 1981 . Since new economic policies were introduced about 5 years ago, a significant growth in the major sectors of the economy such as Agriculture, Forestry and Fisheries was noted. The mineral sector that is identified under "Mining and Quarrying" has also expanded in a rapid manner with the expansion in the Gem Trade and the export of Petroleum products. In order to contribute to the export earnings of the country in a more significant manner the minerals sector has to expand more rapidly. The major constraint in expansion of our mineral sector is the lack of a proper assessment of the mineral resources of Sri Lanka. 


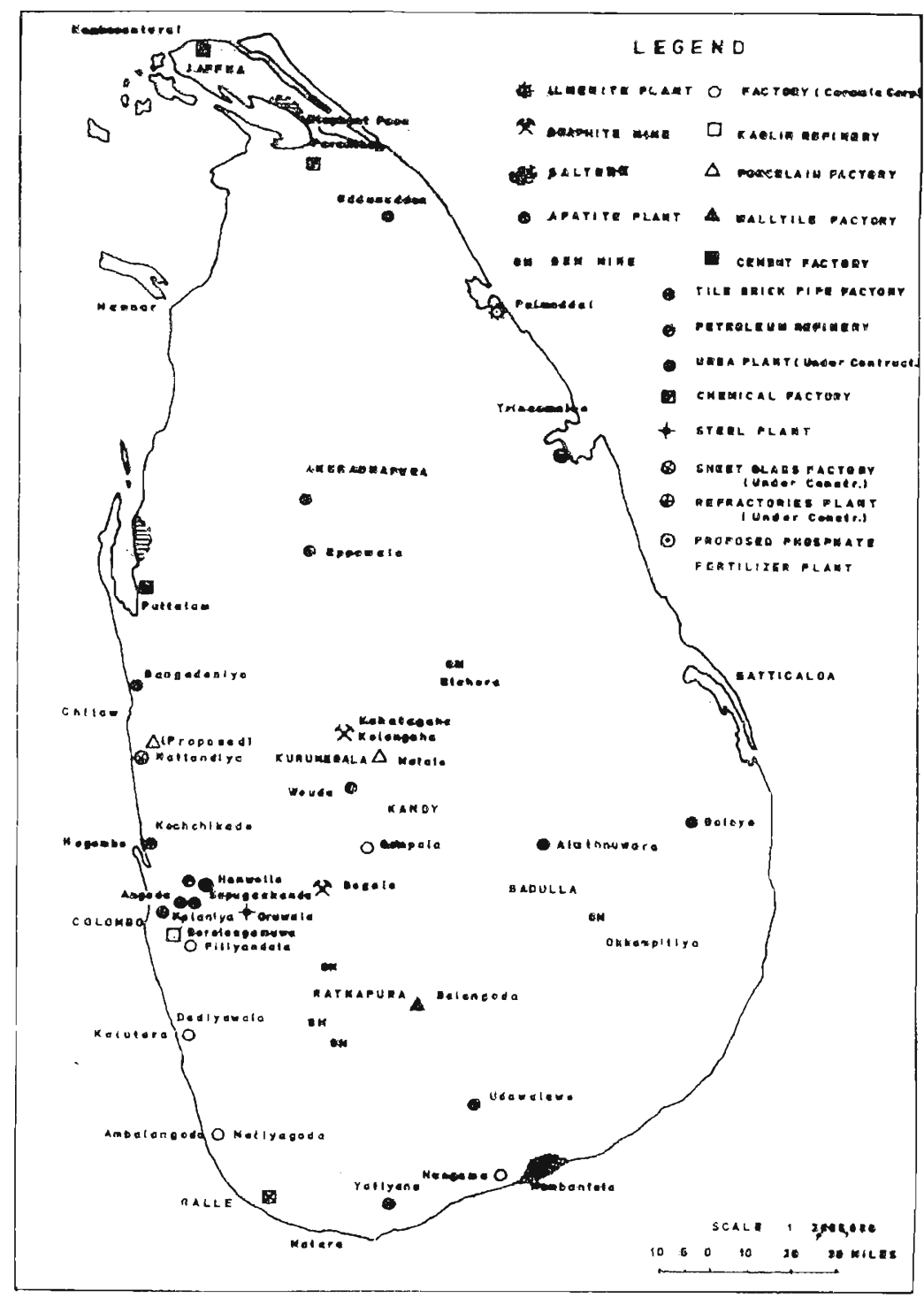

Figure 1. Location of industrial Units and Mines - Sri Lanka (After Herath 1980) 
The Geological Survey Department during. the recent past has taken up the challenge of locating new mineral deposits with the main objective of expanding the already established mineral based industries such as ceramics, graphite, mineral sands, steel and fertilizer. An attempt is made in this paper to identify the commercially exploitable mineral resources of the Island and how these resources are utilized by the mineral based industries.

\section{Development of Mineral Surveys}

The first attempt to assess the mineral resources of Sri Lanka was during the period 1903 - 1906, when the British colonial regime set up a mineral survey headed by Dr. Ananda Coomaraswamy. The past records of the mineral survey indicate that all major river beds, streams and the coast line were traversed and panned concentrates were collected to identify any base metals. Most of the samples were sent to the Imperial Institute in London for identification. These heavy concentrates indicated the presence of copper, zinc, chromium, nickel, thorium and other metals. The significant discoveries made during this period were thorianite from Bambarabotuwa in the Ratnapura area and graphite deposits in the South-West sector of the Ysland. Occurrence of limonitic iron-ores specially in the hill country was also noted and the records of this survey had indicated that a local iron and steel industry was in existence during the past.

In 1940, systematic and organised geological survey activities were undertaken by the then Department of Mineralogy uncier the direction of Dr. D. N. Wadia whose main objective was in identifying the main lithological divisions of the Island.

In 1945, L. J. D. Fernando was appointed Head of the Department of Mineralogy and his main task was to build-up a permanent staff consisting of trained Geologists to undertake systematic geological mapping and mineral exploration programmes. The Mineralogy Department was re-organised and was named the Geological Survey Department in 1961.

Detailed geological mapping of the Island commenced in 1954 and mineral cxploration activities were undertaken mainly to assess mineral raw materials for the mineral based industries such as cement, ceramics, steel and mineral sands.

The state sector industrial corporations which presently utilize minerals as basic raw materials were established without a proper assessment of the quality and quantity of such raw materials that are available. The Geological Survey Department was called upon to play a major role in locating such raw material and give necessary advice on exploitation. The lack of modern equipment and trained personnel were the major drawbacks in the assessment of the mineral potential of Sri Lanka at this early stage. In 1958, the Department purchased core dritling machines and other geophysical instruments and these equipment helped in a 
significant manner to undertake systematic mineral exploration programmes. The analytical facilities were also improved and from 1960 the Department was capable of assessing minerals by way of quantity and quality for the major mineral based industries such as cement arud ceramics. The Department also was entrusted with the task of developing all the major floor sheets for heavy mineral separation which was to be undertaken by the Mineral Sands Corporation at their commercial heavy mineral processing plant at Pulmoddai.

The above history of the development of the Geological Survey Department is closely tied with the discoveries of mineral resources in Sri Lanka. It must be stated that the Geological Survey Department was the major organisation in this country that identified the presently exploitable mineral resources.

\section{The present Assessment of Mineral Resources}

The Geological Survey Department completed the systematic Geological mapping of the Island in 1976 on a reconnaissance scale of 1:63,360 ( 1 " to 1 Mile). During the course of this programme two significant mineral discoveries were made. These two discoveries are (a) The Eppawela Rock Phosphate Deposit in the Anuradhapura District and (b) The Seruwila Copper Magnetite Deposit in the Trincomalee District. These two discoveries will be dealt with later in this paper.

The Department also undertook a systematic stream sediment and heavy mineral panning programme with the main objective of detection of uranium mineralisation and base metals in 1979. These surveys are presently continuing and have given satisfactory results.

A proposal to upgrade the Institutional facilities of the Geological Survey Department to undertake mineral exploration programmes in a more systematic manner was presented to the Government in 1980. This proposal is now under consideration and if accepted by the Government the Asian Development Bank will provide funds to the extent of about US $\$ 30$ million for the modernisation of the Institutional facilities. The setting up of a Marine Geology Unit within the Department has also been proposed.

The planned expansion of the Geological Survey Department will be a vital pre-requisite in the complete assessment of the mineral resources of Sri Lanka and will help in preparing a mineral resources inventory which will in turn help all the major mineral sector industrial organisations in their expansion programmes.

\subsection{The Mineral Resources of Sri Lanka}

An attempt is made to describe the mineral resources of Sri Lanka according to the various industrial sectors that presently utilize or exploit such resources for industry or export. 


\subsection{The Ceramic Industry}

The major ceramic raw materials presently utilized in industry are:
(a) Clays
(b) Kaolin
(c) Ball Clay
(d) Feldspar
(c) Vein Quartz

(a) Clays: The pioneer work of Herath $^{2}$ has established three main clay mineral provinces in the Island. These three clay provinces are identified as (1) montmorillonite-kaolinite clays with minor amounts of calcareous materials confined to the dry zone in the north and south-east. (2) Gibbiste-kaolinite clays with mixed layer mineral confined to the wet zone and (3) clays of the intermediate zone between (1) and (2). These clay mineral provinces closely follow the three climatic zones of the Island and the exploitable clay deposits for tiles and bricks are located mainly in the intermediate zone. Areas where such clays are presently exploited. on a commercial scale are in the Maha-Oya basin north of Negombo, Weuda, Aluthnuwara, Yatiyana and Uda-Walawe. It is estimated that the total annual requirements of clays mainly for the brick, tile and pipe industry is about 1500 acre feet both by the public and private sectors. The Ceylon Ceramics Corporation operates 10 tile factories and produce about 75 million tiles per annum.

A proper assessment of clay resources suitable for brick and tile manufacture has not been undertaken. The Geological Survey Department has carried out clay surveys for almost all the major state sector tile factories and it is now opportune to compile a report on the availability of such clays and assess the future requirements. A complete assessment of the exploitable clay resources in the Maha-Oya basin is suggested as this area sustains the major brick and tile factories in the Island operated both by the public and private sectors. Reclamation of land where clay is presently exploited has to be given serious thought and advice on exploitation is vital specially when such clay deposits are located close to valuable paddy lands.

An assessment of the Jurassic shales present in large quantities at Andigama and Tabbowa as a source of raw material for the manufacture of heavy clay products including refractories should be undertaken.

(b) Kaolin: The occurrence of china clay or kaolin in the low lying areas around Colombo have been known in the past. The Boralasgamuwa kaolin deposit presently exploited by the Ceylon Ceramics Corporation is estimated to contain about 1 million tons. However, no detailed surveys have been undertaken to estimate the reserves of raw kaolin present in the vicinity of the Boralasgamuwa kaolin 
field. Kaolin is also reported from the Horton plains area and other deeply weathered zones of the Central Highlands. The Meetiyagoda kaolin field located in the south-west sector of the Island is also exploited by the Ceylon Ceramics Corporation but a proper assessment of this field has not been undertaken.

The Ceylon Ceramics Corporation presently operates two kaolin refineries and produces about 7,000 tons of refined kaolin per annum.

It is suggested that a proper assessment of the kaolin fields in the Island should be undertaken and a planned exploitation programme initiated so as to conserve this valuable raw material for the expansion of the ceramic industry.

(c) Ball Clays: Clays which approach ball clay in composition are known to occur in the flood plains of rivers confined to the south-west sector. The best known ball-clay deposit is located at Dediyawala near Kalutara and the reserves are estimated at 500,000 tons. A detailed survey has not been undertaken as yet and the reserves are estimated to be much more than known at present. These clays are classed as a refractory bond clay or fire clay (fusion point $1700^{\circ} \mathrm{C}$.)

At present the Ceylon Ceramics Corporation and Lanka Wall Tiles Ltd., utilize the ball clay deposits at Dediyawala. The private sector is also exploring the possibility of extraction of ball-clay and it is suggested that a detailed assessment of the available resources of ball-clay in the Dediyawala area should be undertaken as a matter of priority so that the presently established industries will be assured of a continuous supply of this ceramic raw material. It is also suggested that the Ceramics Corporation and Lanka Wall Tile Ltd., should work out the requirements of ball-clay for the next two decades so that the private sector too could utilize this resource for setting-up new ceramic industries.

(d) Feldspar: In Sri Lanka feldspar is mainly used in the ceramic and glass industry. Microcline feldspar (potash, feldspar) occurs in pegmatites in various parts of the Island specially in the Rattota, Talagoda, Kaikawela, Namal-Oya and Koslanda areas. The largest deposit of feldspar so far discovered is at Owella Estatc (Kaikawela) and is being exploited by the Ceylon Ceramics Corporation.

The total reserves of feldspar in the Island has not bzen estimated as yet, and every effort should be made to carry out detailed surveys with the main objective of assessing the exploitable deposits. It has also been noted that graphic granite (a rock containing quartz and feldspar) occur in various parts of the Island and this rock could be used in the ceramic industry if the correct proportion of quartz and feldspar are present or after crushing to separate the two minerals.

(e) Vein Quartz: Vein Quartz deposits of extreme purity (over 99.8 per cent $\mathrm{SiO}_{2}$ ) are found in various parts of the Island. The best known deposits occur 
in the Opanaike, Pelmadulla, Pussella, Rattota, Ratnapura and Galaha (Ambalamna Estate) areas. Herath ${ }^{2}$ believes that the total reserves exceed 500,000 tons but recent surveys carried out by the Geological Survey have indicated that these reserves could far exceed this figure. Vein quartz is mined at present for use in the ceramic and allied industries.

\subsection{Glass Industry}

At present this industry is not well established although high quality glass sands were known to occur over a century ago. Except for a few private glass factories turning out bottles at present there are no major factories manufacturing sheet glass, ornamental glass and other products. Proposals for the setting up of a sheet glass factory with assistance from the People's Republic of China were pursued by the Ceylon Ceramics Corporation from 1975 but had to be abandoned due to technical reasons.

Deposits of glass sands are located in the Island and the best known deposits occur in the Marawila-Nattandiya and Madampe areas. A significant deposit of glass sand occur in the Ampan-Vallipuram areas of the Jaffna Peninsula. The total extent of the Madampe deposit is about 640 acres.

The average thickness of the glass sand is about 4 feet without any overburden. However, the sand layer is uneven and it is estimated that nearly 6 million tons are available both above and below the water table. The sands are well graded containing over $98 \% \mathrm{SiO}_{2}, 1 \% \mathrm{Al}_{2} \mathrm{O}_{3}$ and less than $0.5 \% \mathrm{Fe}_{2} \mathrm{O}_{3}$ and $\mathrm{TiO}_{2}$. The sands are occasionally mixed with organic matter and other heavy minerals which could be removed by washing.

The glass sand deposit in the Ampan-Vallipuram area occurs in the form of dunes. The area is devoid of any infra-structure facilities such as roads and the development of this deposit will depend on improving of such facilities. The main drawback is the absence of fresh water in the area. It is suggested that a detailed survey should be carried out to ascertain the tonnages and other parameters of this deposit.

There is potential for manufacture of ornamental crystal-ware from high quality quartz present in the Island. Plans are also underway to set up a sheet glass factory within the Free Trade Zone and this factory will utilize the glass sands present in the Marawila-Nattandiya area.

\subsection{The Cement Industry}

The cement industry is well established in the Island as the main raw materials limestone and clay are available specially in the north-western coastal stretch of the Island. The two cement plants at Puttalam and Kankesanthurai are geared to manufacture about 600,000 metric tons of portland cement per annum by the dry process. 
The present expansion programme at Kankesanthurai when completed will add another 400,000 metric tons of cement per annum to the above production.

The Miocene limestone that is presently used for cement manufacture is well developed in the Jaffna Peninsula and stretches as a narrow belt along the north west coast as far as Puttalam. The calcium carbonate content of this limestone is over $95 \%$ and the reserves proved by the Department both at Puttalam (Aruwakalu) and Kankesanthurai are over 100 million tons.

The limestone deposit at Mannar which was earlier earmarked for a third cement plant has a reserve of over 30 million tons and could far exceed this figure once detailed surveys are completed. This deposit is not exploited at present as the infra-structure facilities available in Mannar are inadequate at present to set up a cement plant.

The limestone at Aruwakalu which is exploited for the Puttalam cement works has excess silica due to the presence of marl intermixed with the limestone. Serious problems were experienced at the Puttalam plant due to the impure nature of this limestone and the Geological Survey Department was called upon to carry out additional drilling investigations in order to locate pure limestone in 1975 1976.

These surveys revealed that pure Miocene limestone is present in the southwestern part of the Aruwakalu Hill and the Ceylon Cement Corporation has now opened a new quarry in this area. In addition to these surveys the Geological Survey Department carried out drilling investigations in the Dutch Bay adjacent to this area and proved about 35 million tons of miocene limestone of acceptable quality on the bed of the Dutch Bay to a depth of about 50 meters. Environmental problems have dissuaded the Cement Corporation from exploiting these reserves.

In order to plan the future expansion of the cement industry a careful assessment of the total exploitable reserves of miocene limestone in the Puttalam-MannarJaffna coastal belt has to be undertaken. The Islands off the Jaffna Peninsula contain pure coral deposits and an example of such an occurrence is the Delft Island. Coral limestone is ideal for cement manufacture by the wet or dry process and mining costs will be low.

It is interesting to note that the Akurala swamp close to Ratgama contains coral which could be profitably exploited as it is an inland deposit. A proper assessment of the quality and quantity available may help in deciding whether a small scale cement kiln could be established. This proposition will also help in running the Ruhunu cement works on a profitable basis as this plant has excess capacity for grinding clinker and other facilities such as packing Portland cement. The clinker from a plant close to Akurala could be easily transported to Galle for this purpose. 
The private sector has entered the cement industry with the commencement of construction work on a clinker grinding and cement packing plant at China Bay, Trincomalee. This joint venture is between a local collaborator and a Japanese firm. Most of the cement manufactured from this plant will be exported thus earning valuable foreign exchange.

\subsection{The Gem Industry}

The Gem industry is of the greatest antiquity and in the old scriptures it has been recorded that Sri Lankan gems were brought to the Court of Solomon. Greek writers also refer to Sri Lankan gems during the 1 st and 2 nd centuries. The Arabs and the Persians also exercised a considerable influence over the gem trade of the Island, during the 4 th and 5 th centuries. It is believed that nowhere in the world are there so many gem minerals concentrated in a comparatively restricted area of mountainous country such as the Ratnapura gem field. Upto recent times it was generally believed that gemstones occur only in the Ratnapura District but during the recent past gemstones in abundance have been located in the Elahera, Okkampitiya, Embilipitiya and Madampe areas.

The precious and semi-precious stones of Sri Lanka with the exception of Moonstones which are mined from fresh or weathered rock are won from gravels in river beds, buried river valleys and swamps. These gem bearing gravels consist of residual minerals which have withstood the process of weathering, crosion and transport during the past geological ages.

At present extensive gemming activities are carried out in the Ratnapura, Elahera, Okkampitiya, Embilipitiya, Madampe, Eheliyagoda and Rakwana areas. Gemstones have been recently found in the Kantalai area. Most of the gem mining activities are carried out by small scale miners using traditional methods. Coomaraswamy (1903 - 1906) describes these traditional gem mining methods in great detail in the Administration Reports for 1903-1906.

With a view to develop the gem mining industry of Sri Lanka the State Gem Corporation was established in 1971. The Corporation handles the issue of permits for gem mining, cutting and polishing of gemstones and the export of gem parcels. The Corporation has also entered the jewellery trade and has made significant contributions in putting the gem industry on a sound footing. In 1981, gemstones to the value of US $\$ 32$ million were exported, from Sri Lanka. Attractive tax concessions such as exemption from export duty on gemstones have been introduced in order to promote exports.

The main varieties of gemstones present in Sri Lanka are sapphires, rubies and cats' eyes. Apart from these precious stones a large variety of semi-precious stones belonging to the garnet, spinel, zircon and tourmaline varieties are also present. 
In 1979, the State Gem Corporation invited offers from loreign and local companies for allocation of lands to carry out large scale gem mining in areas that are to be inundated under the multipurpose Mahaweli programme. Nearly 35 firms were interested at the initial stage but only 9 firms submitted detailed proposals. This project was unsuccessful due to the fact that the companies had to negotiate with private land owners for access to the proposed reservoir beds. The highly rugged nature of the terrain earmarked as reservoirs were not suitable for large scale mechanised gem mining as heavy machinery could not be moved into such areas.

\subsection{The Steel Industry}

The Ceylon Steel Corporation was established in 1961 for the purpose of implementing the steel project which included the setting-up of a rolling mill and a wire mill under stage I. The rolling mill and wire mill was commissioned in 1967. This mill has a capacity of 80,000 metric tons per annum (on three shifts) and imported steel billets are converted to standard shapes to meet the requirements of the building industry. Cold twisted high strength ribbed tor-steel for the purpose of reinforcing concrete is also produced. The wire mill has a capacity to produce 12,000 metric tons per annum. Under stage II of the expansion programme a continuous casting electro-smelting plant has been commissioned and this plant is capable of utilizing the local scrap iron.

Stage III of the expansion programme envisages the utilization of local iron-ore.

The iron-ore deposits of Sri Lanka could be broadly categorised as follows:-

(a) Deposits of hydrated iron oxide-limonite and goethite present as boulders and near surface deposits.

(b) Magnetite deposits

The limonitic iron ores are mainly concentrated in the south-west part of the Island particularly in the Ratnapura District and to a lesser extent in the Galle and Matara Districts. The ore is generally found in the form of boulders and hill cappings and generally extend to a depth of about 12 feet. The deposits are highly scattered and nearly 50 such deposits are known in the Ratnapura, Rakwana, Balangoda and Kalawana areas. Individual deposits are known to be highly variable in tonnage ranging from 10,000 to 150,000 . The total reserves of limonitic iron-ores are estimated at about 2.2 million tons of exploitable grade. The most important deposits occur in the Dela, Noragolla, Opata and Poranuwa areas of the Ratnapura District with an average iron content varying from 53 to 54 percent. 
The main drawback in utilizing the limonitic deposits in the local steel industry is the scattered nature and the high phosphorous content $\left(0.74 \% \mathrm{P}_{2} \mathrm{O}_{5}\right)$.

Three magnetite deposits were discovered by the Geological Survey Department at Wilagedara (1959), Panirendawa (1962) and at Seruwila (1971).

The Wilagedara deposit is too small and is of no economic significance. The deposit at Panirendawa is known to contain 5.6 million tons of high grade magnetite which is easily amenable to beneficiation and could be concentrated to give $a+65$ percent $\mathrm{Fe}$ fraction. This deposit however is broken into four separate blocks structurally and cannot be mined as a single unit. The other drawback in the exploitation of this deposit is that it occurs at depths ranging from 30 to 125 meters below ground level and expensive mining methods will have to be adopted for extraction.

The Seruwila magnetite deposit is on the surface and is the most promising deposit of iron-ore found so far in the Island. The magnetite is known to be associated with apatite and copper minerals such as chalcopyrite, bornite and cupreferous pyrite. An advanced exploration programme conducted jointly by the Geological Survey Department and the French BRGM has proved nearly 4 million tons with $40 \%$ soluble iron upto a depth of about 100 meters.

A pre-feasibility study on the utilization of the Seruwila magnetite for the local steel industry will have to be undertaken keeping in mind the separation and concentration of copper minerals and apatite.

\subsection{Industries Based on Export of Minerals}

1. Graphite Industry: The graphite industry is over 150 years old and had its boom periods during the 1st and 2nd World Wars when nearly 35,000 metric tons per annum were exported. During this period nearly 6,000 shallow workings, pits and small scale mines were in operation. The industry had its downfall during the post 2 nd World War period when the demand for natural graphite and prices in the world market fell considerably. Since 1950, only about 4 large scale mining operations were in existence and from 1965 only the Bogala, Kahatagaha and Kolongaha Mines continued their mining activities.

The graphite mining industry was nationalised in 1971 with the takeover of the Bogala Mines from the private sector. In 1972 the Kahatagaha / Kolongaha mining operations were taken over and the State Graphite Corporation (now State Mining and Mineral Development Corporation) was established.

Graphite occurs in the Island in veins, pegmatites and disseminated flakes in the country rocks. At present only vein graphite is exploited and two working mines are operated by the State Mining and Mineral Development Corporation 
at Bogala and Kahatagaha/Kolongaha. These two mines have gone down to depths over 2000 feet and the present machinery in these mines are over 50 years old. The Corporation has replaced certain machinery in order to maintain a production level of about $8,000-10,000$ metric tons of raw graphite per annum.

Sri Lankan natural graphite is of the highest purity and grades over $95 \%$ carbon are common. This variety of graphite is of the crypto-crystalline type and is utilized in the refractory industry, manufacture of carbon brushes, crucibles, dry torch cells, batteries, carbon cinema arcs, paints and lubricants. The State Mining and Mineral Development Corporation is also engaged in the marketing of natural graphite and the main customers are in Japan, U.K. and USA. Graphite is marketed according to the carbon content and particle size. Sri Lankan natural graphite is presently facing severe competition from other sources of origin such as the People's Republic of China and Brazil.

The traditional markets for Sri Lankan natural graphite have been lost during the last 2 years due to indiscriminate price increases and lack of proper market intelligence within the Corporation. In order to regain our traditional markets a more real'stic pricing policy has to be adopted and the requirements of customers specifications have to be met. Every effort should also be made to identify collaborators for setting up graphite based industries in Sri Lanka. The total reserves of natural graphite is not known and a systematic exploration programme has to be initiated to assess the potential specially in the graphite bearing belt that runs from the south-central part of the island to the north-east.

2. The Beach Mineral Sands Industry: The Ceylon Mincral Sands Corporation was established in 1957 primarily for the exploitation of the Pulmoddai heavy sands deposit. The Corporation now operates an integrated mineral separation plant at Pulmoddai for the separation of ilmenite, zircon and rutile. The present facilities have a capacity to produce 85,000 tons ilmenite, 11,000 tons of rutile, and 8,000 tons of zircon per annum. Ilmenite, rutile, zircon and monazite occur in the beach sands of Sri Lanka but the heavy concentration at Pulmoddai has made only this deposit economically viable for exploitation.

Pulmoddai is located along the north-eastern coast of Sri Lanka and is about $80 \mathrm{~km}$ from Trincomalee. The deposit is about $10 \mathrm{~km}$ in length with an average width of about 100 meters. It is estimated to contain about $6,000,000$ tons of heavy sands with an average composition of $70-72 \%$ ilmenite, $8-10 \%$ zircon, $8 \%$ rutile and $0.3 \%$ monazite. About $1 \%$ sillimanite is also present. The Pulmoddai deposit is one of the best known in the world. The heavy sands are collected by scraping the beach and it is known that this deposit is seasonal where the sands ate brought by waves during the north-east monsoon. The seasonal replenishment of the sands have not been studied and such studies will help in ascertaining the quantities that are brought to the shore annually. 
As a part of the expansion of the beach mineral sand industry a complete assessment of the coastal area between Mullaitivu and Nilaweli was undertaken by the Geological Survey Department in 1979. As a result of this survey three very promising deposits at Nayaru, Koduwakattumalai and Tavikkalu were located. A detailed exploration programme undertaken by a foreign firm has conclusively proved a reserve of 475,000 to 700,000 tons of rutile, 350,000 to 500,000 tons of zircon and 2 to 4 million tons of ilmenite.

The future expansion programmes of the Ceylon Mineral Sands Corporation include the setting up of wet-magnetic separators for increasing the production of heavy sands, electro-smelting of ilmenite to produce titanium slag and the setting up of a titanium pigment plant. The upgrading of ilmenite to produce synthetic rutile is also being considered by the Corporation.

\section{Recent Mineral Discoveries in Sri Lanka}

Two significant mineral discoveries were made in $197 \mathrm{l}$ by the Geological Survey Department during the systematic geological mapping programme of the Island. These two discoveries are:

(a) The Eppawela rock phosphate deposit;

(b) The Seruwila copper-magnetite deposit.

(a) The Eppawela Rock Phosphate Deposit: The Eppawela rock phosphate deposit was discovered by the Geological Survey Department during the systematic geological mapping of the 1" topographical sheet of Anuradhapura. Eppawela is located on the Kekirawa-Talawa Road and is approximately 110 miles from Colombo.

This phosphate deposit is of the carbonatite type and the main phosphatic minerals are (1) chlor-fluorapatite and (2) francolite (carbonate apatite). The other minerals present in this rock are iron carbonates of the martite and goethite type.

The major deposit has a surface area of about 1000 acres and consists of six elevated hillocks rising to a maximum altitude of 200 meters above mean sea level. (Kiriwelhinna Hill). The exploitable ore zone consists of a brecciated rock with a modal composition of over $80 \%$ phosphate bearing minerals. This zone extends below the surface to an average thickness of about 70 meters from the crests of the hills.

The average $\mathrm{P}_{2} \mathrm{O}_{5}$ grade of this phosphate rock is about $36 \%$ and the main drawback in utilizing this ore for wet process phosphoric acid manufacture is its high chloride content (av. $1 \%$ ) and the high $\mathrm{Fe}_{2} \mathrm{O}_{3}+\mathrm{Al}_{2} \mathrm{O}_{3}$ contents (av. over $5 \%$. The acceptable limits for industry is $0.05 \%$ chloride and $4 \% \mathrm{Fe}_{2} \mathrm{O}_{3}+\mathrm{Al}_{2} \mathrm{O}_{3}$. 
Since the discovery of the Eppawela rock phosphate deposit the Geological Survey Department carried out an extensive exploration programme that included the drilling of 27 deep holes. These investigations have proved a firm reserve of 25 million tons of phosphate rock with an average grade of $36 \% \quad \mathrm{P}_{2} \mathrm{O}_{5}$ for only a part of the northern sector of the deposit. The proved and inferred reserves are now estimated at about 60 million tons.

The various Agricultural Research Institutes in Sri Lanka initiated research studies from 1972 to ascertain the use of this valuable mineral resource as a phosphate fertilizer for direct application. These studies were successful for the tea sector and the rubber sector. At present the State Mining and Mineral Development Corporation is producing an average of 15,000 metric tons per annum of ground phosphate rock with a minimum of $35 \% \mathrm{P}_{2} \mathrm{O}_{5}$ and $85 \%$ passing the 100 BSS Mesh. The recent field trials by the Rubber Research Institute have shown that the ground Eppawela rock phosphate is suitable for the entire rubber sector except a small area in marshy soils of the south-west where granulated NPK fertilizer is used.

In order to assess the suitability of the Eppawela rock phosphate for the manufacture of wet process phosphoric acid, a research programme was under taken by the International Fertilizer Development Centre in Alabama, USA in late 1979. These studies have revealed that the Eppawela phosphate rock could be used for manufacture of high analysis phosphatic fertilizer such as di-ammonium phosphate and triple super phosphate but an industrial method of removal of the high chloride, iron and aluminium has to be identified by carrying out further pilot plant tests.

The Ministry of Industries and Scientific Affairs in April 1979 called for proposals from international firms engaged in manufacture of phosphate fertilizer to participate on a joint venture basis to develop the Eppawela phosphate deposits. Twenty-five inquiries from plant contractors, consulting firms and organisations engaged in operating phosphatic fertilizer plants were received and on the recommendations of an Evaluation Comimttee, the Cabinet Sub-Committee on Economic Development has approved in principle the proposal from Agrico Chemical Company, Tulsa, USA, to develop the phosphate deposit at Eppawela.

A special Committee is now scrutinising the agreements and it is hoped that the final approval from the Government to go ahead with this project will be given soon.

This project envisages the manufacture of 530,000 tons per annum di-ammonium phosphate entirely for export and 50,000 tons per annum of triple super phosphate for local use. The research studies conducted by the Agrico Chemical Co., 
at their own expense since 1979 have been successful and a practical methods of processing the Eppawela rock to manufacture wet process phosphoric acid has been identified.

If all approvals by the Government are received before the end of 1983, the proposed phosphate fertilizer plant with foreign collaboration will be on-stream by $1989-1990$.

(b) The Seruwila Copper-Magnetite deposit: The Seruwila copper-magnetite deposit was discovered by the Geological Survey Department in 1971 during the systematic geological mapping of the 1" topographical sheets of Trincomalee and Kathiraveli. Seruwila is located in the Trincomalee District and can be approached from the Kantalai-Seruwila-Muttur Road. This prospect is about $275 \mathrm{~km}$ from Colombo and is located in one of the most inaccessible areas of Sri Lanka.

The exploration work conducted by the Geological Survey during the period 1971 - 1977 included geological mapping, geochemical and geophysical surveys and drilling operations. This work revealed that the ore is widely scattered and exposed in three areas namely Arippu, Block "C" and Kollankulam. In 1979 a joint advanced exploration programme was initiated by the Geological Survey Department in collaboration with the French BRGM. This programme was carried out over a period of one and a half years and four reports on the quantity and quality of the ore are now available.

The final report has revealed that approximately 4 million tons of exploitable ore upto a depth of 100 meters are available only in the Arippu area. The average grade of the ore is $1.5 \%$ copper with $40 \%$ soluble iron as Fe.

The Seruwila copper-magnetite prospect is most promising as a source of iron-ore for the Oruwela Steel plant and a feasibility study has to be conducted to draw up long term plans for its exploitation.

The Seruwila ores consist primarily of magnetite and the copper-sulphide minerals are chalcopyrite, pyrite, and cupreferous pyrite. Traces of pentlandite, borenite, azurite, tellurides, etc., were also detected during this exploration programme.

\section{Target Areas for future Exploration}

(a) Eastern Highland/Vijayan Boundary: With the discovery of the Seruwila copper magnetite deposit which is the first base metal find in Sri Lanka, a new area for exploration was opened. The location of the Seruwila ores on the boundary between the Highland/Vijayan (the two major lithological zones) indicate that this boundary is a potential target area for base metal mineralization. This boundary 
which is approximately $25 \mathrm{~km}$ wide and $550 \mathrm{~km}$ long has to be examined very carefully for detection of base metals such as copper, cobalt, zinc, etc. The analytical data of the Seruwila ores have also revealed minor amounts of silver, gold, and tellurides (platinum bearing minerals). Basic rocks such as pyroxenites, amplibolites and peridotites are identified as host rocks for base metals and these rocks have been found in the Seruwila drill cores.

A systematic exploration programme should be undertaken as a matter of priority to detect any base metal mineralization along the Highland/Vijayan boundary. Such a programme should include detailed geological mapping, integrated geochemical and geophysical surveys and diamond core drilling.

It is also suggested that an integrated airborne magnetic/radiometric survey be carried out to pinpoint target areas for exploration on the ground if funds could be obtained under existing aid programmes.

The present geological information along the Highland/Vijayan boundary in the south-eastern part of the Island has also revealed that serpentinite outcrops in the form of ring structures exist and some of these serpentinites showing lateritic characteristics have anomalous nickel value. ${ }^{1}$ This discovery will be followed-up by the Department during the detailed programme for investigating the Highland Series/Vijayan Series boundary.

(b) Stream sediment panning programme for Detection of Uranium: The Geological Survey Department initiated a stream sediment panning programme covering the entire Precambrian basement of the Island in 1979 with the main objective of detection of uranium and other base metal mineralization. This programme was conducted with the assistance of the International Atomic Energy Agency (IAEA) of the United Nations.

The IAEA in Vienna made available an expert to plan out this stream sediment sampling programme. The results of this initial survey were reviewed by another expert at the beginning of 1983 and nine target areas have been identified for further follow-up work which will include the collection of samples on a closer grid, radon gas-surveys collection of chip samples and diamond core drilling.

The total area for the follow-up work is $6780 \mathrm{sq} \mathrm{km}$ and this area has been selected from the original area of $60,000 \mathrm{~km}^{2}$ covered by the preliminary survey.

The Geological Survey Department is carrying out these follow-up surveys on a continuous basis and hopes to complete the entire programme during a period of 5 years. Assistance from foreign geological surveys and exploration companies will be of great help to complete these surveys before the target date. 


\section{Conclusions}

An attempt has been made to describe the mineral resources of Sri Lanka and highlight the present status of mineral resource development in context with the established mineral based industries. Minerals are non-renewable resources and the exploitation and utilization of such resources should be carried out on a carefully planned long-term programme. A comprehensive inventory of the available mineral resources presently utilized in industry should be drawn up as a matter of priority keeping in mind the annual consumption. Immediate steps should be taken to assess the potential of the mineral resources presently utilized in industry and adequate safeguards should be taken to ensure regular supplies. The exploration for new mineral deposits should also be undertaken by the Geological Survey Department on a long-term plan so as to sustain and expand the existing mineral sector industries and start new industries based on future mineral discoveries. The 5 year Public Investment Programme of the Government drawn up by the Ministry of Finance and Planning for 1983-1987 has stressed the need for increased export earnings and the mineral sector has been identified as an area where rapid growth could be achieved. In order to realise this objective the Government should provide all assistance to upgrade the present institutional facilities of the Geological Survey Department, as such facilities will be a vital pre-requisite in the proper assessment of the economically exploitable mineral resources of Sri Lanka.

\section{References}

1. Dissanayake, C. B. (1982). The Geology and Geochemistry of the Uda-Walawe Serpentinite, Sri Lanka. J. Natn. Sci. Coun. Sri Lanka 10 (1): 13-34.

2. Herath, J. W. (1980). Mineral Resources of Sri Lanka Economic Bulletin No. 2 (Second Edition Revised) Geological Survey Department. 